\title{
Epidemiology of Invasive Fungal Infections in Latin America
}

\author{
Jose Sifuentes-Osornio • Dora E. Corzo-León • \\ L. Alfredo Ponce-de-León
}

Published online: 5 January 2012

(C) The Author(s) 2011. This article is published with open access at Springerlink.com

\begin{abstract}
The pathogenic role of invasive fungal infections (IFIs) has increased during the past two decades in Latin America and worldwide, and the number of patients at risk has risen dramatically. Working habits and leisure activities have also been a focus of attention by public health officials, as endemic mycoses have provoked a number of outbreaks. An extensive search of medical literature from Latin America suggests that the incidence of IFIs from both endemic and opportunistic fungi has increased. The increase in endemic mycoses is probably related to population changes (migration, tourism, and increased population growth), whereas the increase in opportunistic mycoses may be associated with the greater number of people at risk. In both cases, the early and appropriate use of diagnostic procedures has improved diagnosis and outcome.
\end{abstract}

Keywords Epidemiology · Invasive fungal infections · Endemic infections - Opportunistic infections - Candidemia . Cryptococcosis · Cryptococcus · Aspergillosis · Filamentous fungi $\cdot$ Mold fungi $\cdot$ Mucormycosis $\cdot$ Fusariosis .

Histoplasmosis · Coccidioidomycosis .

J. Sifuentes-Osornio $(\bowtie) \cdot$ L. A. Ponce-de-León

Laboratory of Microbiology, Salvador Zubiran National Institute of Medical Science and Nutrition,

15 Vasco de Quiroga, sección XVI, Tlalpan,

México City, ZC 14000, Mexico

e-mail: sifuentesosornio@gmail.com

L. A. Ponce-de-León

e-mail: alf.poncedeleon@gmail.com

D. E. Corzo-León

Infectious Diseases, Salvador Zubiran National Institute

of Medical Science and Nutrition,

México City, Mexico

e-mail: cold200781@hotmail.com?
Paracoccidioidomycosis · Latin America · South America .

Central America · Brazil · Colombia · Mexico · Ecuador .

Argentina $\cdot$ Chile $\cdot$ Cuba $\cdot$ Panama $\cdot$ Uruguay $\cdot$ Paraguay .

Bolivia $\cdot$ Costa Rica

\section{Introduction}

The pathogenic role of invasive fungal infections (IFIs) has increased during the past two decades. As diagnostic tools have been improved and the number of patients with an immunosuppressive state (HIV, hematopoietic stem cell transplantation [HSCT], chemotherapy for cancer patients, autoimmune diseases) has risen dramatically, clinicians and scientists have begun to look more deeply into the mechanisms of disease and their relationship with susceptible populations. Working habits (agriculture, livestock activities) and leisure activities have also been the focus of attention by public health officials, as a number of outbreaks of endemic mycoses have been considered to be a result of exposure to higher inoculum of microorganisms in their natural habitat $[1,2 \cdot, 3 \cdot 4-8]$. The number of scientific publications has also increased, particularly in high-resource countries, though this is not the case in Latin America, where only a few groups of scientists (in Brazil, Colombia, and Argentina) have reported their experiences, mainly discussing epidemiologic surveillance (incidence, prevalence, morbidity and mortality rates, and risk factors). A number of relevant reviews recently have become available.

This article is divided into two sections: endemic mycoses and opportunistic IFIs, with special emphasis on histoplasmosis, coccidioidomycosis, paracoccidioidomycosis, cryptococcosis, invasive candidiasis, and aspergillosis and infection by other filamentous fungi. 


\section{Endemic Mycosis}

Histoplasmosis

This is the most prevalent disseminated mycosis in Central America, in the so-called histo belt of the central United States (particularly in the Ohio and Mississippi river valleys), and in the southeastern regions of Mexico. Histoplasma capsulatum lives in soil, especially under alkaline conditions ( $\mathrm{pH}$ between 5 and 10) and with ambient temperatures between $20^{\circ} \mathrm{C}$ and $30^{\circ} \mathrm{C}$. Dormant and active infections have been observed in miners, geologists, guano workers, farmers, and archeologists. Several outbreaks have been observed after accidental exposure to large quantities of bird and bat droppings in in endemic areas. Several cases have been reported in European and US citizens as well as local tourists who visited caves in Belize, Costa Rica, Dominican Republic, Ecuador, Guatemala, Mexico, and Peru (Fig. 1) [4, 9, 10].

The reported annual incidence in México was 0.29/ 100,000 inhabitants between 1953 and 1997, whereas in the United States, the incidence was much higher, at 3.4/ 100,000 inhabitants. Prevalence studies using skin testing have shown reactivity between $5 \%$ and $50 \%$ in different regions, mainly reflecting dormant infection. This type of infection has also been found in other regions, such as in northeastern Argentina (Tucuman), with a prevalence of $4.5 \%$ to $67 \%$; la Serra do Mar in Brazil; the Pampa Humeda; and the Parana and Uruguay river valleys, Venezuela, Ecuador, and Colombia [11-14, 15•, 16].

Two biotypes infect humans: $H$. capsulatum var capsulatum and $H$. capsulatum var duboissii; however, eight clades have been defined by molecular tools: 1 and 2 in North America, A and B in Latin America (clade A more common in Brazil and clade B in Colombia and Argentina), and the Australian, Indonesia/Netherland, Euroasiatic, and African clades. Several polymorphisms have been detected in the yps 3 gene, which encodes a surface protein; its expression has been related to virulence. These polymorphic fragments also show a geographical distribution: polymorphisms 3, 5, and 6 are more commonly found in Latin America and 2 is found in North America [10, 17, 18, 19•].

Histoplasmosis is considered an AIDS-defining illness. In Latin America, the prevalence varies between $2.1 \%$ and $20 \%$; it is an AIDS-defining infection in $30-75 \%$, usually seen in patients with fewer than $100 \mathrm{CD} 4+$ cells. Pulmonary disease is the most common presentation, followed by cutaneous involvement; disseminated disease is found in up to $50 \%$ of the cases. In Latin America, histoplasmosis is concomitantly diagnosed with tuberculosis in $10 \%$ to $20 \%$ of cases with disseminated disease, whereas this co-infection is observed in only $4 \%$ of patients in Europe and the United States [14, 15•, 20-22].
Several genetic differences between North American and South American strains have been identified using molecular typing methods that may explain clinical and experimental differences among HIV co-infected patients. South American strains usually behave more aggressively [23, 24]: in Mexico, for example, strains EH-53 and EH-46 have been isolated from non-HIV patients and strains EH316-19, EH323, and EH325 from HIV patients. Dermatotropism is also more common in South American isolates, with cutaneous involvement seen in $40 \%$ to $80 \%$ of patients (up to $90 \%$ in reports from Argentina and Panama), compared with fewer than $20 \%$ of US patients [25*0]. Polymorphisms of the internal transcribed spacer (ITS) region (based on 7 positions) have been associated with two cutaneous variants, $\mathrm{Hc} 1$ and $\mathrm{Hc} 2$; these variants have been observed in Brazil, Argentina, Colombia, and Asia and were absent on North American isolates [10, 17, 19•, 26].

According to the 2007 guidelines of the Infectious Diseases Society of America (IDSA), the first-choice treatment for discrete to moderate histoplasmosis should be itraconazole, and for severe forms, amphotericin with prednisone followed by itraconazole [27].

\section{Coccidioidomycosis}

This endemic IFI is caused by species of Coccidioides. It is highly prevalent in dry regions $(<600 \mathrm{~mm}$ of annual rainfall) with high temperatures. The natural habitat of the species is $5 \mathrm{~cm}$ to $30 \mathrm{~cm}$ below the surface of alkaline soils. Weather conditions are usually extreme, ranging between $0^{\circ} \mathrm{C}$ and $45^{\circ} \mathrm{C}$. The two distinct species are endemic in different regions: $C$. immitis in the San Joaquin Valley in California and C. posadasii in Arizona, Texas, Mexico, Central America, and South America. DNA sequencing of $C$. posadasii has enabled investigators to approximate the geographic origin of the infection. Restriction fragment length polymorphisms also are useful in identifying the two species. Zimmermann groups I and II correspond to C. immitis and $C$. posadasii, by means of five differences in nuclear genes (CHS1, pyrG, tcrP, serine-proteinase antigen, CTS2) and nine single nucleotide polymorphisms (SNPs) [3•, 12, 28••].

There are three distinct endemic areas in Mexico: the north (near the US border), the Pacific coast, and the central valley. Skin testing using coccidioidin has revealed a prevalence of $5 \%$ to $30 \%$. In Central America, two endemic areas have been identified, the Motagua River valley in Guatemala and the Comaya valley in Honduras, with positive skin testing up to $42 \%$. In South America, four countries have areas with high prevalence: in Argentina, the Sierras Pampeanas; in Colombia, the Magdalena, Guajira, and Cesar provinces; in Paraguay, the area of the Great Chaco; and in Venezuela, the 


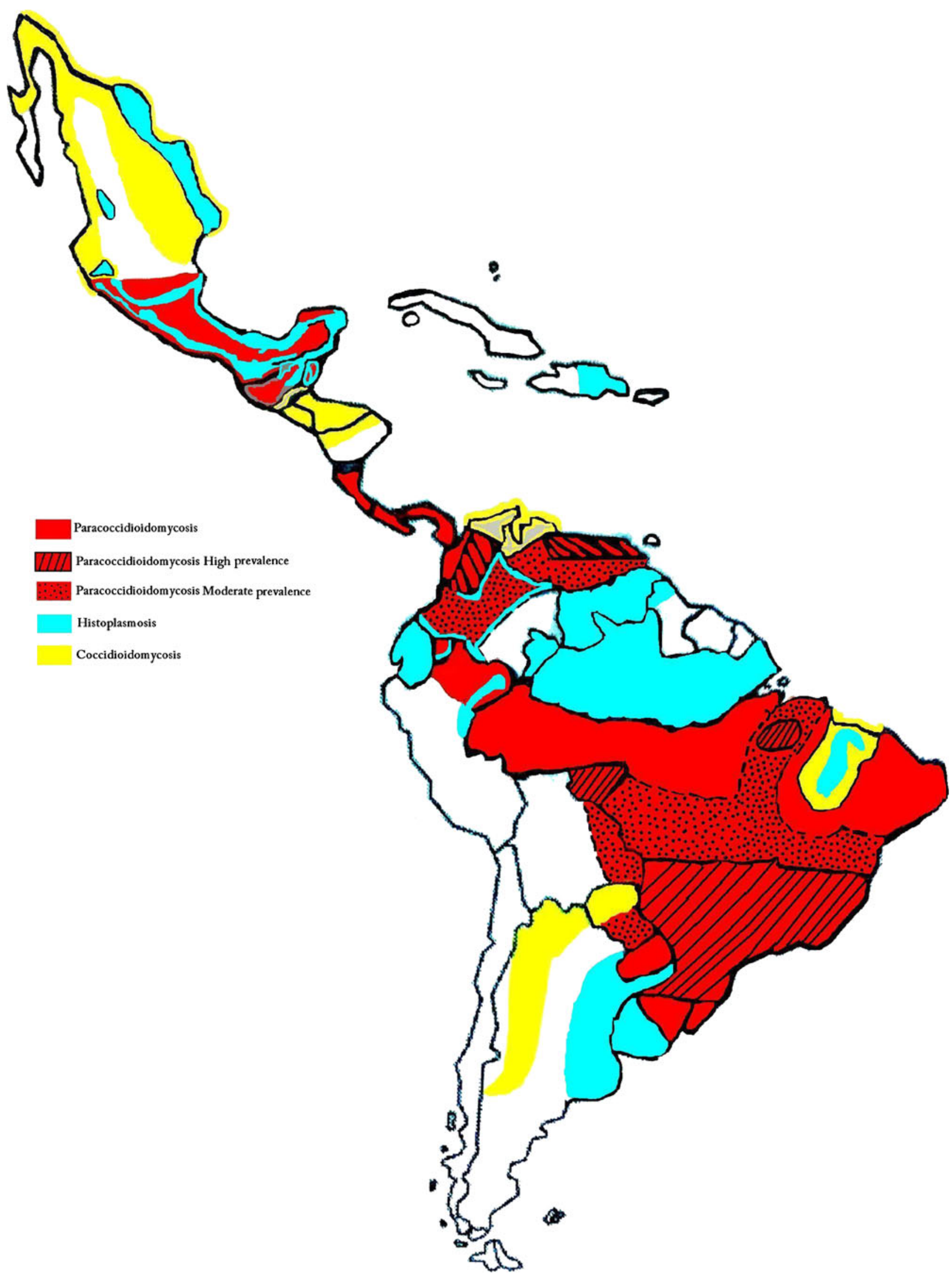

Fig. 1 Geographic distribution of endemic fungal infections in Latin America 
Departments of Falcon, Lara, and Zulia (Fig. 1). Brazil is not an endemic region, but several outbreaks in the Piaui and Ceará districts have been reported in association with armadillo hunting [3•, 12, 29, 30•, 31].

Increased incidence has recently been reported in Argentina and the United States, mainly owing to migration and new settlements in high-risk areas. In Catamarca, Argentina, the incidence rates grew from 0.6 cases per 100,000 inhabitants before 2006 to 2.1 in 2009. Most cases in the United States and Mexico occur in individuals younger than 5 or older than 55 years. In contrast, the higher incidence rates observed in South America involve those 25 to 35 years of age. Pulmonary outbreaks usually have been associated with earthquakes, military encampments, construction sites, and archaeologic excavations [31-35].

Up to $40 \%$ of those infected develop the disease, but less than $1 \%$ of these patients have progressive pulmonary disease with dissemination, which mostly affects patients with associated risk factors such as HIV, diabetes mellitus, chemotherapy, transplantation, or third-trimester pregnancy. This last situation favors disseminated disease 40 to 100 times more often than in the general population, and mortality rates increase up to $90 \%$. Individuals of African American or Asian descent have the greatest incidence and risk of dissemination, whereas Hispanics have the lowest incidence. Another independent risk factor is the presence of an allele (HLA-II DRB1*1301) on chromosome 6p21.3 $[3 \cdot, 11,35,36]$.

Clinical manifestations are usually pulmonary, with reticular and/or miliary disease that can progress to frank cavitations. In Latin American patients, the most common manifestations of disseminated disease are cutaneous, osteoarticular, or meningeal. Coinfection with tuberculosis has been reported occasionally, especially in white men and Hispanic migrants [29, 37, 38].

Treatment with amphotericin B, itraconazole, or fluconazole is recommended for severe pulmonary or disseminated disease. Only amphotericin B is recommended for pregnant women $[39,40]$.

\section{Paracoccidioidomycosis}

This is a South American endemic IFI caused by dimorphic species of the Paracoccidioides brasiliensis complex. This complex is comprises three species (S1, PS2, and PS3). In endemic regions, the prevalence of the infection may be as high as $75 \%$, affecting both men and women; $1-2 \%$ will present active disease. About $1.4 \%$ of cases are coinfected with HIV. Of all active cases, $80 \%$ are reported in Brazil, especially in the south and southeast regions, where the annual incidence is 10 to 30 cases per 1,000,000 inhabitants. In other regions, such as north Argentina, Venezuela, and Colombia, the incidence is much lower, about 2.4 cases per
$1,000,000$ inhabitants. Sporadic cases have been reported in México (Veracruz) and Central America, with several imported cases found in Spain and Japan. P. brasiliensis remains confined to particular geographic areas (Fig. 1), predominantly in tropical and subtropical regions with moderate temperatures $\left(17^{\circ}-24^{\circ} \mathrm{C}\right)$ and heavy rain $(>1,400 \mathrm{~mm}$ of annual rainfall) $[3 \bullet, 11,28 \bullet \bullet, 41,42 \bullet \bullet, 43]$.

Molecular epidemiology performed by RFLP/RAPD analyses have identified subspecies that affect particular regions: the S1 polymorphism predominates in Brazil, Argentina, Paraguay, Peru, and Venezuela; PS2 in Brazil and Venezuela; and PS3 exclusively in Colombia (the main differences are on SNPs on the gp43 gene). Variations in virulence, susceptibility to sulfonamides, and accuracy in serodiagnosis have been related with different polymorphisms, principally between S1 and PS2 [44•, 45].

The disease is associated with exposure to the fungus in agriculture, specifically in cotton, coffee, and tobacco plantations; decreased risk has been observed in plantations, such as sugar plantations, that are heavily treated with pesticides.

Tobacco consumption seems to be associated with a predominance of chronic disease in men 30 to 60 years of age (13-70:1 ratio). This predominance could be related to a protective effect of $\beta$ estradiol in women. Although women can be readily infected, estrogens seem to affect the mycelial-to-yeast transition, and they also seem to increase the secretion of interferon- $\gamma$ and the levels of TH1 cells and decrease the levels of interleukin (IL)-10 [43, 46•], as shown in experimental models. In a retrospective study, $82 \%$ of 27 women with paracoccidioidomycosis were menopausal, and in several studies conducted in prepubertal children, the rate of disease was similar in both sexes; this clinical finding supports the

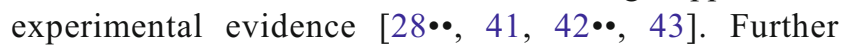
population-based studies are needed to corroborate the protective influence of estrogens in women and to determine the labor risk in urban and rural areas.

Culture is still the diagnostic gold standard. In tissue, the fungus is abundantly present with yeast cells, which allow for direct diagnosis by fine-needle aspiration. Serodiagnosis is based on identification of specific antibodies by immunodiffusion. Antigen detection is also available by identification of $g p 43$ by enzyme immunoassay [42••, 45].

Chronic pulmonary or pharyngeal infections account for $90 \%$ of cases. Pulmonary involvement is usually interstitial, followed by fibrosis [47-50]. Although it is the most common cause of death by a systemic mycosis in Brazil (followed by cryptococcosis), mortality rates vary between 1.18 and 3.48 deaths per million inhabitants [51]. The treatment of choice is itraconazole, which has been demonstrated to be superior to other antifungals in several comparative clinical trials [50]. 


\section{Opportunistic Mycosis}

\section{Candidemia}

Hospital-acquired infections frequently cause morbidity and mortality. Candida bloodstream infections are a good example; they are the fourth most common cause overall of hematogenous infections in the United States, and they rank fourth to seventh in Europe [1, 52]. In multicenter studies conducted in Brazil and in Mexico, it has been found that $4 \%$ of nosocomial bloodstream infections are caused by Candida species [53-55]. C. albicans is the most frequently isolated yeast worldwide. In the United States, C. glabrata is the second, but in Latin America, C. tropicalis and $C$. parapsilosis are the most important species after $C$. albicans $[54,56]$. C. tropicalis is usually isolated from neutropenic patients and other immunocompromised hosts, perhaps because of the extensive use of prophylactic fluconazole in the region. C. parapsilosis has been associated with central venous catheter infections because of its ability to form biofilms, and it has been a significant pathogen in neonatal intensive care units $[2 \cdot 54,56]$, even more important than C. albicans [57-61].

The incidence of bloodstream fungal infections is 0.28 to 0.96 per 1,000 admissions in the United States and 0.2 to 0.38 in Europe, whereas in Latin America these rates vary between 1.2 and 5.3 ( $0.2-0.5$ cases per 1,000 patient-days) $[1,2 \cdot, 54,55,57]$. Preliminary data in two referral centers in Mexico City showed an incidence rate of 2.8 cases per 1,000 hospital discharges, which corresponded to 0.38 per 1,000 patient days (Table 1) [53].

Crude mortality rates of about $40 \%$ have been reported worldwide; in reports from Brazil, Mexico, Argentina, Chile, Colombia, and Costa Rica, the mortality rates vary between $20 \%$ and $63 \%[53,54,59,62-64]$. Lower mortality rates have been reported in outbreaks caused by C. parapsilosis [60, 63], but this rate seems to vary between different age groups: $24 \%$ to $34 \%$ in neonatal intensive care units; $43 \%$ in children less than 1 year old; $23 \%$ in children $1-12$ years of age; and $40 \%$ to $63 \%$ in adults (Table 1) [53, 54, 60, 65].

In Latin America, amphotericin B desoxycholate continues to be the antifungal drug most commonly used, followed by fluconazole [54, 55, 62, 66, 67]. Echinocandins and other amphotericin B formulations are rarely used because of their higher cost.

Antifungal resistance studies have been conducted globally and regionally. Overall resistance to FCZ varies between $1 \%$ and $6 \%$. However, when analyzed by species, resistance to fluconazole in C. albicans, C. parapsilosis and C. tropicalis is less than $3 \%[54,55,58,60-63]$. Resistance to fluconazole in C. tropicalis has been reported in up to $6 \%$ to $8 \%$ of cases, but these results could be influenced by "the trailing phenomenon" seen in susceptibility testing. $C$. glabrata and C. krusei are usually more resistant (30\% and $70 \%$, respectively) $[58,67,68]$. In these large studies, resistance to amphotericin $\mathrm{B}$, echinocandins, or voriconazole has not been found [69••].

\section{Cryptococcosis}

Cryptococcosis is caused by a complex group of basidiomycetes, usually yeasts of $2-10 \mathrm{~mm}$ in diameter. This complex is called Cryptococcus neoformans and is divided in two varieties: $C$. neoformans var neoformans (serotypes A and D, genotypes VNI-IV) and C. neoformans var gattii (serotypes B and C, genotypes VGI-IV). About $95 \%$ of cases are caused by var neoformans, and serotype A (var grubii) is responsible for $95 \%$ of those. This pathogen has ubiquitous distribution. C. gattii is endemic in tropical and subtropical regions, and is usually observed in immunocompetent individuals [70].

Cryptococcosis is the most important cause of fungal meningoencephalitis worldwide, affecting immunocompetent as well as immunocompromised individuals. It may cause other clinical patterns, such as fungemia, pneumonia, and lesions of bone, skin, and soft tissue. Meningoencephalitis is the most common clinical form of cryptococcosis in Latin America, with $85 \%$ of cases caused by C. neoformans [71]; $80 \%$ are associated with HIV infection [72, 73].

More than 215,000 patients with AIDS and cryptococcosis were observed between 1980 and 2002, and 60\% of the patients were concomitantly diagnosed [72]. The prevalence of meningitis in Mexico has been about $7 \%$ to $11 \%$ in patients with HIV, with a decreasing trend in recent years [2•]. Some studies reported Cryptococcus to be the fourth or fifth most common yeast isolated in blood cultures; sometimes it is even more common than C. glabrata [28••, 60].

The incidence of cryptococcal meningitis varies according to the population being studied. In Rio de Janeiro, the incidence was $0.3 / 100,000$ inhabitants in 2002 , increasing to 0.68 in 2003 [73]. In Colombia, this rate was determined to be $0.24 / 100,000$ inhabitants among the general population, but 3/1,000 in HIV patients [74].

A multicenter Ibero-American study done in 2003 collected 340 strains derived from humans, animals, and soil and found that $C$. neoformans var grubii (serotype A) was the most common species (56\% to $93.3 \%$ ). The VNI genotype was the most common in Mexico, Guatemala, Venezuela, Brazil, Colombia, Peru, Chile, and Argentina ( $45 \%$ to $93.3 \%$ ). C. neoformans var gattii was isolated in $3 \%$ to $41 \%$, and the VGI and VGIII genotypes were the most frequent. Of note, genotypes VNIV and VGII were not identified in Mexico in this study, but a later report found these genotypes in two isolates from Mexico (Table 2) [28••, 71, 75]. 
Table 1 Candidemia in Latin America: Recent case series and clinical surveillance studies

\begin{tabular}{|c|c|c|c|c|c|c|c|}
\hline Study & Design & $\begin{array}{l}\text { \# of cases/\# } \\
\text { of hospitals }\end{array}$ & Identification & Place/Years & Mortality & $\begin{array}{l}\text { Incidence per } \\
1,000 \text { admissions } \\
(1,000 \text { patient- } \\
\text { years })\end{array}$ & Resistance \\
\hline \multicolumn{8}{|l|}{ Brazil } \\
\hline Colombo et al. [55] & MOPS & $712 / 11$ & $\begin{array}{l}\text { C. albicans } 41 \% \\
\text { C. tropicalis } 20.9 \% \\
\text { C. parapsilosis } 20.5 \%\end{array}$ & 4 cities in Brazil/2003-4 & $54 \%$ & $2.49(0.37)$ & $1 \%$ to $\mathrm{FCZ}$ \\
\hline Colombo et al. [54] & MOPS & $282 / 4$ & $\begin{array}{l}\text { C. albicans } 38 \% \\
\text { C. parapsilosis } 23 \% \\
\text { C. tropicalis } 17 \%\end{array}$ & Sao Paulo/2002-3 & $61 \%$ & 1.6 & $\begin{array}{l}2 \% \text { to } \mathrm{FCZ}(C \text {. glabrata, } \\
\text { C. rugosa) }\end{array}$ \\
\hline $\begin{array}{l}\text { Bruder-Nascimento et al. } \\
\text { [57] }\end{array}$ & SOPS & $102 / 1$ & $\begin{array}{l}\text { C. albicans } 32.4 \% \\
\text { C. parapsilosis } 48 \% \\
\text { C. guilliermondii } 6.9 \%\end{array}$ & Sao Paulo/1998-2005 & & & $\begin{array}{l}14.6 \% \text { to } \mathrm{FCZ} \\
\quad(\text { C. glabrata } 68 \%)\end{array}$ \\
\hline \multicolumn{8}{|l|}{ Mexico } \\
\hline González et al. [58] & MOPS & $5 / 398$ & $\begin{array}{l}\text { C. parapsilosis } 37.9 \% \\
\text { C. albicans } 31.9 \% \\
\text { C. tropicalis } 14.8 \% \\
\text { C. glabrata } 8 \%\end{array}$ & Monterrey/2004-7 & & & $\begin{array}{l}2.4 \% \text { to } \mathrm{FCZ}(31 \% C . \\
\text { glabrata })\end{array}$ \\
\hline $\begin{array}{l}\text { Hernández-Dueñas et al. } \\
\text { [62] }\end{array}$ & SORS & $1 / 112$ & $\begin{array}{l}\text { C. albicans } \\
\text { C. tropicalis } \\
\text { C. parapsilosis }\end{array}$ & México D.F/1992-2007 & $63 \%$ & & $\begin{array}{l}1.8 \% \text { to } \mathrm{FCZ}(\mathrm{C} \text {. glabrata } \\
40 \%)\end{array}$ \\
\hline Corzo et al. [53] & MOPS & $2 / 74$ & $\begin{array}{l}\text { C. albicans } 45.9 \% \\
\text { C. tropicalis } 25.7 \% \\
\text { C. glabrata } 13.5 \%\end{array}$ & México D.F/2008-10 & $46 \%$ & $2.8(0.38)$ & \\
\hline \multicolumn{8}{|l|}{ Colombia } \\
\hline Diaz-Granados et al. [59] & $\mathrm{CC}$ & $1 / 18$ & $\begin{array}{l}\text { C. albicans } 38.9 \% \\
\text { C. parapsilosis } 16.7 \% \\
\text { C. glabrata } 5.5 \% \\
\text { C. tropicalis } 5.5 \%\end{array}$ & Bogotá/2004 & $33 \%$ & $(0.25-1.1)$ & \\
\hline Rodríguez et al. [68] & MOPS & 195 & $\begin{array}{l}\text { C. albicans } 41.8 \% \\
\text { C. tropicalis } 22.9 \% \\
\text { C. parapsilosis } 19.9 \%\end{array}$ & Medellín/2001-7 & & & $\begin{array}{l}\text { 9.5\% to FCZ }(18.8 \% \\
\text { C. glabrata, } C . \\
\text { parapsilosis } 14.9 \% \text {, } \\
\text { C. krusei } 100 \%, C \text {. } \\
\text { guilliermondii } 50 \% \text {, } \\
\text { C. famata } 50 \%) 3.6 \% \\
\text { to VOR }(\text { C. glabrata } \\
15.6 \% \text {, C. krusei } \\
18.2 \%) \text {. }\end{array}$ \\
\hline Cortés et al. [104] & MOPS & $1,622 / 27$ & $\begin{array}{l}\text { C. albicans } 44.7 \% \\
\text { C. parapsilosis } 13.6 \% \\
\text { C. tropicalis } 13.6 \%\end{array}$ & Colombia/2001-7 & & & \\
\hline \multicolumn{8}{|l|}{ Venezuela } \\
\hline Arcaya et al. [63] & MOPS & $74 / 1$ & $\begin{array}{l}\text { C. parapsilosis } 29.7 \% \\
\text { C. tropicalis } 27 \% \\
\text { C. albicans } 28 \%\end{array}$ & Maracaibo/2000-2 & & & $\begin{array}{l}2.7 \% \text { intermediate to } \\
\text { FCZ }(\text { C. glabrata, } \\
\text { C. parapsilosis }) .\end{array}$ \\
\hline Panizo et al. [64] & MOPS & $33 / 15$ & $\begin{array}{l}\text { C. albicans } 9.1 \% \\
\text { C. parapsilosis } 48.5 \% \\
\text { C. tropicalis } 21.2 \%\end{array}$ & Venezuela/2006-7 & & & $\begin{array}{l}6 \% \text { to } \mathrm{FCZ} \text { (C. krusei } \\
100 \% \text {, C. tropicalis } \\
3 \% \text {, C. glabrata } 9 \%)\end{array}$ \\
\hline \multicolumn{8}{|l|}{ Argentina } \\
\hline Santos et al. [65] & SORS & $1 /$ & $\begin{array}{l}\text { C. parapsilosis } 32.6 \% \\
\text { C. albicans } 26.5 \% \\
\text { C. tropicalis } 24.5 \%\end{array}$ & Buenos Aires/2001-3 & $20.8 \%$ & & \\
\hline \multicolumn{8}{|l|}{ Chile } \\
\hline Ajenjo et al. [67] & SOPS & $1 / 22$ & $\begin{array}{l}\text { C. albicans } 44.4 \% \\
\text { C. tropicalis } 27.7 \% \\
\text { C. glabrata } 11 \%\end{array}$ & Chile/2001-3 & $16.6 \%$ & & $\begin{array}{l}\text { No resistance to } \mathrm{FCZ} \text { in } \\
\text { C. albicans }\end{array}$ \\
\hline
\end{tabular}

MOPS Multicenter, observational prospective study, SOPS Single center, observational prospective study, SORS Single center, observational retrospective study, $C C$ case-control study, FCZ fluconazole, VOR voriconazole 
Most cryptococcosis cases (75-95\%) occur in HIVinfected young men $(<40$ years old) [75-77]. In this subgroup, C. neoformans var grubii genotype VNI has been the most frequent pathogen isolated, and most of the patients show counts below $100 \mathrm{CD} 4+$ cells $[71,74,76-78]$.

da Cunha Colombo et al. [73] reported 81 HIV-infected patients with cryptococcosis; $50 \%$ died before receiving highly active antiretroviral therapy (HAART), and among those who received treatment, $25 \%$ showed signs of immune reconstitution syndrome (IRIS), and $33 \%$ of the latter group died. Cryptococcosis is the second most frequent cause of death as a result of a fungal infection in Latin America. Mortality rates in Africa and Latin America are unacceptably high (31\% to $75 \%$ ) when compared with $20 \%$ in developed nations. Alcoholism and high lactate dehydrogenase (LDH) levels ( $>400 \mathrm{U} / \mathrm{L}$ ) have been found to be significant risk factors for death $[47,72,73,78,79]$.

Patients without HIV infection usually have other immunosuppressive conditions that predispose them to this infection. The immunosuppression in these cases has been attributed to defects in the cellular immune response as part of the disease or conditioned by immunosuppressive therapy, as seen in patients with systemic lupus erythematosus, transplant recipients, and patients with malignancies who are undergoing chemotherapy [73]. However, recent reports have found no underlying disease in $5-10 \%$ of the patients with cryptococcosis; this situation may delay diagnosis and treatment and worsen the outcome [74, 76, 77].

Antimicrobial susceptibility surveillance studies have shown that more than $99 \%$ of the isolates are susceptible to amphotericin B, fluconazole, and flucytosine. Pfaller et al. [80] analyzed 1,811 isolates from five different geographic regions and showed that isolates from Latin America had results similar to those from other regions.

Lizarazo et al. [74] reported susceptibility of 93 strains between 1997 and 2005, finding that more than 97\% of them were susceptible to amphotericin B. He also found that isolates of $C$. neoformans var grubii were $100 \%$ susceptible to fluconazole and itraconazole, but $C$. gattii isolates were only $88 \%$ susceptible to these agents.

Current treatment guidelines for cryptococcal meningoencephalitis recommend the use of amphotericin B desoxycholate plus flucytosine, but in Latin America, $80 \%$ of patients are treated with amphotericin B desoxycholate and fluconazole, with results similar to those of the standard treatment [76-78].

Infection by Aspergillus and Other Filamentous Fungi

IFIs caused by Aspergillus species, Fusarium, Mucormycosis, Scedosporium, Trichosporon, Rhodotorula, Alternaria, Bipolaris, and Curvularia have been extensively described in patients with hematologic neoplasias, transplant recipients 
(especially bone marrow transplants), persons living with diabetes, and patients under chronic high-dose steroid treatment. In Latin America, IFIs have been described that were caused by this group of pathogens, especially Candida and Aspergillus ( $>90 \%$ of the cases). In the same group of patients, the more relevant risk factors were profound neutropenia, monocyte count less than 100 cells for more than 4 days, and elevated serum level of reactive protein C [81].

In patients with profound neutropenia and fever, up to $7 \%$ of the cases are caused by an IFI. After candidemia, the most important pathogens involved are Aspergillus spp, Fusarium spp, and mucormycosis agents. In Latin America, bronchopulmonary aspergillosis has been reported as the third leading cause of deep mycosis, and mucormycosis as the eighth most common cause in some general hospitals [82], [83•, 84]. Characteristically, diagnosis can only be established by histopathologic findings such as angioinvasion or by the isolation of these pathogens from the bloodstream.

\section{Aspergillosis}

Candida spp and Aspergillus spp are responsible for $80 \%$ to $90 \%$ of all IFIs. A large amount of knowledge about Aspergillus has been accumulated recently, especially regarding its biology, epidemiology, risk factors for infection, host characteristics, clinical pictures (acute invasive sinusitis, allergic sinusitis, pulmonary invasive aspergillosis, allergic bronchopulmonary aspergillosis, aspergillomas, intestinal and cutaneous aspergillosis), treatment, and preventive strategies. Studies have considered all types of patients, but most have emphasized patients with hematologic neoplastic diseases or bone marrow transplant recipients. Aspergillus is the most common cause of IFI in patients with allogenic HSCT in Latin America, with a bimodal distribution (before posttransplant day 30 or after day 90), and it is the second most common cause in solid-organ transplant recipients. Aspergillosis occurs in 3\% of patients with bone marrow transplants and in $1.3 \%$ of hepatic transplants, rates higher than the reported incidence in surveillance studies in the United States and Europe [5-7]. The most common species is A. fumigatus, and the most common clinical presentation is pulmonary, followed by sinusitis $[81,85,86]$.

Diagnostic tools that have been implemented include culture, histopathology, and serologic methods; galactomannan in serum by immunoenzymatic assays has proven to be useful when determined in multiple serial samples in several circumstances, including early diagnosis in probable invasive infection (with concomitant improvement in outcome), and therapeutic follow-up to monitor treatment efficacy $[85,87,88]$. Recently, several institutions in Latin America have incorporated its use for the routine evaluation of high-risk patients.
Voriconazole is considered the first-line treatment for this clinical condition, but amphotericin B desoxycholate is still used in Latin America because of economic reasons.

Crude mortality from aspergillosis ranges from $30 \%$ to $83 \%$ worldwide, and mortality rates in Latin America are higher than $70 \%$, especially among HSCT recipients. Mortality in solid-organ transplant recipients is lower than in HSCT recipients worldwide [5-7, 87, 88].

Antimicrobial susceptibility testing in 50 clinical isolates of A. fumigatus (from México, Peru, Argentina, and France) showed a splendid susceptibility to itraconazole $\left(\mathrm{MIC}^{90}=\right.$ $0.25 \mathrm{mg} / \mathrm{mL}$ ), voriconazole (MIC ${ }^{90}=0.25 \mathrm{mg} / \mathrm{mL}$ ), and amphotericin $\mathrm{B}\left(\mathrm{MIC}^{90}=1 \mathrm{mg} / \mathrm{mL}\right)$, similar to other results from two recent international studies [89, 90].

\section{Fusariosis}

One of the most common mold IFIs seen in immunocompromised patients is caused by Fusarium spp septated fungi. Three clinically important species have been recognized: $F$. solani, $F$. oxysporum, and $F$. verticillioidis. These IFIs are therapeutic challenges worldwide because Fusarium spp are often resistant to most antifungal agents. Fusariosis causes fungemia $(>60 \%)$ in immunocompromised patients, with or without endocarditis, skin lesions (60-80\%), sinusitis, and lung disease. In immunocompetent patients, fusariosis tends to be a superficial infection (keratitis and onychomycosis) or to cause locally invasive skin or soft-tissue infection [91].

Brazilian investigators reported an overall incidence of 5.97 cases per 1,000 HSCT recipients; HLA-mismatched related-donor HSCT recipients showed the highest incidence and autologous HSCT recipients, the lowest. A trimodal distribution of fusariosis (early, late, and $>1$ year after receipt of HSCT) has been described, and Fusarium is well known as the second most important invasive filamentous fungi in immunocompromised hosts.

The crude mortality rate reported in Latin America is 66\%, but in patients with disseminated disease and persistent immunodeficiency (as in prolonged neutropenia and monocytemia and chronic high doses of corticosteroid), mortality is as high as $100 \%$; similar results were reported in the TransplantAssociated Infection Surveillance Network (TRANSNET) database [5, 6, 92, 93].

Management of this IFI depends on accurate identification. The first line of therapy is high-dose amphotericin B desoxycholate $(>1.5 \mathrm{mg} / \mathrm{kg}$ per day). Voriconazole can be used as a second choice, and posaconazole and other antifungal combinations have been described as salvage therapy in cases of invasive fusariosis. Adjunctive treatment is based on identification of cases requiring surgical debridement and patients who can tolerate less immunosuppressive therapy as well as granulocyte colony-stimulating factors [94]. 


\section{Mucormycosis}

Caused by hyaline aseptate fungi, the most common species are Mucor, Rhizopus, Rhizomucor, and Lichtheimia (previously Absidia), although Cunninghamella Bertholletia and Apophysomyces elegans also are frequent causes.

Multicenter studies have described an increase in the incidence of mucormycosis, which has become the third leading cause of IFI among high-risk immunocompromised patients, after Aspergillus and Fusarium. Major risk factors for mucormycosis include profound and prolonged neutropenia and chronic high-dose corticosteroid use, as well as tissue iron overload, uncontrolled diabetes, hypertriglyceridemia, voriconazole prophylaxis (mainly in HSCT), or previous skin and soft-tissue trauma [8, 95]. The most commonly seen clinical forms are rhinocerebral, pulmonary, osteomuscular and skin diseases.

Some clinical reports and brief series of cases in Latin America have been published, all of which share the same characteristics: late diagnosis, biopsy as the main tool in diagnosis, and high mortality rate. The mortality rate has decreased with the use of combined therapy using antifungal drugs and extensive surgical debridement [95-103].

\section{Conclusions}

An extensive search of the medical literature from Latin America seems to show that the incidence of IFIs has increased for both endemic and opportunistic fungal infections. The increase of endemic IFIs is probably related to population changes (migration, tourism, and increased population growth), whereas the change in the incidence of opportunistic IFIs is likely to be associated with an increase in the number of people at risk. In both cases, the early and appropriate use of standard and new diagnostic procedures has improved the diagnosis and patient outcomes.

Histoplasmosis has shown interesting characteristics. It seems to be more aggressive because of some genetic characteristics, as evidenced by more frequent skin involvement among Latin American patients. In addition, tuberculosis plays a major role as coinfection in people living with HIV in this part of the world.

Opportunistic IFIs caused by yeasts have been extensively studied in Latin America, where the incidence of bloodstream infections due to Candida appears to be higher than in Europe and the United States. In addition, the Candida species distribution in this region is different, probably due to strong variations in the quality of health care for high-risk patients.

IFIs caused by filamentous fungi have increased in the past two decades, and an additional increase in the number of these IFIs should be expected. Invasive mold infections have a high mortality rate because of poor drug susceptibility, a greater population with prolonged immunocompromise, and the lack of appropriate tools to obtain an early diagnosis. Therefore, multicenter and large clinical, epidemiologic, and susceptibility surveillance studies are needed in Latin America to improve our comprehension of the IFIs among the population at risk.

Disclosure J. Sifuentes-Osornio: member of advisory board of Pfizer, Merck Sharp and Dohme, and GlaxoSmithKline, travel funding from Biomerieux; D. Corzo-León: none; L. Ponce-de-León: member of advisory board of Pfizer, Merck Sharp and Dohme, and GlaxoSmithKline, travel funding from Merck, Sharp and Dohme.

Open Access This article is distributed under the terms of the Creative Commons Attribution Noncommercial License which permits any noncommercial use, distribution, and reproduction in any medium, provided the original author(s) and source are credited.

\section{References}

Papers of particular interest, published recently, have been highlighted as:

- Of importance

-• Of major importance

1. Pfaller MA, Diekema DJ. Epidemiology of invasive candidiasis: a persistent public health problem. Clin Microbiol Rev. 2007;20:133-63.

2. • Nucci M, Queiroz-Telles F, Tobón AM, et al. Epidemiology of opportunistic fungal infections in Latin America. Clin Infect Dis 2010;51:561-570. This is the only article describing IFIs in Latin America from a clinical perspective. It contains some recent and some classic information produced in Latin America.

3. - Colombo AL, Tobón A, Restrepo A, et al. Epidemiology of endemic systemic fungal infections in Latin America. Med Mycol 2011;49(8):785-98. These authors describe both new and old information about endemic IFIs, including the authors' experience.

4. Sánchez-Alemán MA. Histoplasmosis in travelers [Histoplasmosis del Viajero]. Enf Inf Microbiol. 2009;29:111-6.

5. Kontoyiannis DP, Marr KA, Park BJ, et al. Prospective surveillance for invasive fungal infections in hematopoietic stem cell transplant recipients, 2001-2006: Overview of the TransplantAssociated Infection Surveillance Network (TRANSNET) Database. Clin Infect Dis. 2010;50:1091-100.

6. Pappas PG, Alexander BD, Andes DR, et al. Invasive fungal infections among organ transplant recipients: results of the transplant-associated infection surveillance network (TRANSNET). Clin Infect Dis. 2010;50:1101-11.

7. Lortholary O, Gangneux JP, Sitbon K, et al. Epidemiological trends in invasive aspergillosis in France: the SAIF network (2005-2007). Clin Microbiol Infect 2011;April 25. doi:10.1111/j.14690691.2011.03548.x

8. Kontoyiannis DP, Lewis RE. How I treat mucormycosis. Blood. 2011;118:1216-24.

9. Negroni R, Duré R, Ortiz Nareto A, et al. Histoplasmosis outbreak in Moron, Buenos Aires province, Argentina [Brote de histoplamosis en la Escuela de Cadetes de la Base Aérea de 
Morón, Provincia de Buenos Aires, República de Argentina]. Rev Argent Microbiol. 2010;42:254-60.

10. Muñoz B, Martínez MA, Palma G, et al. Molecular characterization of Histoplasma capsulatum isolates from an outbreak in treasure hunters. BMC Infect Dis. 2010;10:264.

11. Laniado-Laborín R. Coccidioidomycosis and other endemic mycoses in Mexico. Rev Iberoam Micol. 2007;24:249-58.

12. Bonifaz A, Vázquez-González D, Perusquía-Ortiz AM. Endemic systemic mycosis: Coccidioidomycosis, histoplasmosis, paracoccidioidomycosis and blastomycosis. J Detsch Dermatol Ges. 2011;9:705-15.

13. van Gelderen de Komaid, Durán EL. Histoplasmosis in the northwestern Argentina II: Prevalence of Histoplasmosis capsulatum y Paracoccidioidomycosis in the population south of Chuscha, Gonzalo y Potrero in the province of Tucuman. Mycopathology 1995;129:17-23.

14. Mata-Essayag S, Colella MT, Roselló A, et al. Histoplasmosis: a study of 158 cases in Venezuela, 2000-2005. Medicine (Baltimore). 2008;87:193-202.

15. • Cermeño J, Cermeño J, Godoy G, et al. Epidemiological study of paracoccidioidomycosis and histoplasmosis in a suburb of San Félix city, Bolívar State, Venezuela. Invest Clin 2009;50:213220. This paper reports the prevalence rate of these endemic fungal infections for the first time in Latin America, with a supplement on the geographic distribution of these diseases.

16. Baddley JW, Winthrop KL, Patkar NM, et al. Geographic distribution of endemic fungal infections among older persons, United States. Emerg Infect Dis. 2011;17:1664-9.

17. Taylor ML, Chávez-Tapia CB, Rojas-Martínez A, et al. Geographical distribution of genetic polymorphism of the pathogen Histoplasma capsulatum isolated from infected bats, captured in a central zone of Mexico. FEMS Immunol Med Microbiol. 2005; 42:451-8.

18. Gutierrez ME, Canton A, Connolly P, et al. Detection of Histoplasma capsulatum antigen in Panamanian patients with disseminated histoplasmosis and AIDS. Clin Vaccine Immunol. 2008; 15:681-3.

19. - Muniz M de M, Morais e Silva Tavares P, Meyer W, et al. Comparison of different DNA-based methods for molecular typing of Histoplasma capsulatum. Appl Environ Microbiol 2010;76:44384447. In this paper, the authors show clear evidence about molecular differences among Histoplasma capsulatum isolates from Latin America.

20. Velasquez-Uribe G, et al. Histoplasmosis in HIV-patients: a cohort study in Medellin, Colombia. [Histoplasmosis en pacientes con SIDA. Un estudio de Cohorte en Medellín, Colombia]. Infectio. 2010;14:S99-S106.

21. Pontes LB, Leitao Tdo M, Lima GG, et al. Clinical characteristics of 134 patients with disseminated histoplasmosis associated with HIV in the estate of Ceara]. Características clínicoevolutivas de 134 pacientes com histoplasmose disseminada associada a SIDA no Estado do Ceará. Rev Soc Bras Med Trop. 2010;43:27-31.

22. Gutiérrez ME, Canton A, Sosa N, et al. Disseminated histoplasmosis in patients with AIDS in Panama: a review of 104 cases. Clin Infect Dis. 2005;40:1199-202.

23. Karimi K, Wheat JL, Connolly P, et al. Differences in histoplasmosis in patients with acquired immunodeficiency syndrome in the United States and Brazil. J Infect Dis. 2002;186:1655-60.

24. Durkin MM, Connolly PA, Karimi K, et al. Pathogenic differences between North American and Latin American strains of Histoplasma capsulatum var capsulatum in experimentally infected mice. J Clin Microbiol. 2004;42:4370-3.

25. •• Goldani LZ, Aquino VR, Lunardi LW, et al. Two specific strains of Histoplasmosis capsulatum causing mucocutaneous manifestations of histoplasmosis: preliminary analysis of a frequent manifestation of histoplasmosis in southern Brazil. Mycopathology 2009;167:181-186. This report shows evidence about the molecular differences and virulence of Histoplasma capsulatum in Latin America.

26. Bonifaz A, Chang P, Moreno K, et al. Disseminated cutaneous histoplasmosis in acquired immunodeficiency syndrome: report of 23 cases. Clin Exp Dermatol. 2009;34:481-6.

27. Wheat LJ, Freifeld AG, Kleiman MB, et al. Clinical practice guidelines for the management of patients with histoplasmosis: 2007 Update by the Infectious Diseases Society of America. Clin Infect Dis. 2007;45:807-25.

28. •-San-Blas G, Burger E. Experimental medical mycological research in Latin America-a 2000-2009 overview. Rev Iberoam Micol 2011;28:1-25. This is a complete review of the molecular epidemiology research in Latin America done during the past 10 years.

29. Bonifaz A, Vázquez-González D, Perusquía-Ortiz AM. Endemic systemic mycosis: coccidioidomycosis, histoplasmosis, paracoccidioidomycosis and blastomycosis. J Dtsch Dermatol Ges. 2011;9:705-15.

30. - Cordeiro R de A, Brilhante RS, Rocha MF, et al. Twelve years of coccidioidomycosis in Ceará State, Northeast Brazil: epidemiologic and diagnostic aspects. Diagn Microbiol Infect Dis 2010;66:65-72. This paper contains an extensive report of the epidemiologic and the clinical characteristics of coccidioidomycosis in a zone where it is not typically endemic.

31. Canteros CE, Toranzo A, Ibarra-Camou B, et al. Coccidioidomycosis in Argentina, 1892-2009. Rev Argent Microbiol. 2010;42:261-8.

32. Ampel NM. What's behind the increasing rates of coccidioidomycosis in Arizona and California? Curr Infect Dis Rep. 2010;12:211-6.

33. Tsang C, Anderson SM, Imholte SB, et al. Enhanced surveillance of coccidioidomycosis in Arizona, USA, 2007-2008. Emerg Infect Dis. 2010;16:1738-44.

34. Hector RF, Rutherford GW, Tsang CA, et al. The public health impact of coccidioidomycosis in Arizona and California. Int $\mathrm{J}$ Environ Res Public Health. 2011;8:1150-73.

35. Ruddy B, Mayer AP, Ko MG, et al. Coccidioidomycosis in African Americans. Mayo Clin Proc. 2011;86:63-9.

36. Laniado-Laborin R. Expanding understanding of epidemiology of coccidioidomycosis in the western hemisphere. Ann NY Acad Sci. 2007;1111:19-34.

37. Cadena J, Hartzler A, Hsue G, et al. Coccidioidomycosis and tuberculosis coinfection at a tuberculosis hospital: clinical features and literature review. Medicine (Baltimore). 2009;88:66-76.

38. Silva-Hernández AG, Barbachano-Rodríguez E, Alanís-Miranda $\mathrm{PA}$, et al. Tuberculosis and coccidioidomycosis in two patients without immune acquired deficiency [Coexistencia de tuberculosis y coccidioidomicosis en 2 pacientes sin síndrome de inmunodeficiencia adquirida]. Rev Med Inst Mex Seguro Soc. 2010;48: 447-52.

39. Bercovitch RS, Catanzaro A, Schwartz BS, et al. Coccidioidomycosis during pregnancy: a review and recommendations for management. Clin Infect Dis. 2011;53:363-8.

40. Galgiani JN, Ampel NM, Blair JE, et al. Coccidioidomycosis. Clin Infect Dis. 2005;41:1217-23.

41. Nucci M, Colombo AL, Queiroz-Telles F. Paracoccidioidomycosis. Curr Fung Infect Rep. 2009;3:15-20.

42. •- Shankar J, Restrepo A, Clemonds KV, Stevens DA. Hormones and the resistance of women to paracoccidioidomycosis. Clin Microbiol Rev 2011;24:296-313. This is an excellent review about paracoccidioidomycosis, including expert comments and an extensive review of the most important research about the effect of female hormones on Paracoccidioides brasiliensis.

43. Tichellio AG, Mangiaterra M, Giusiano G. Paracoccidioidomycosis in Formosa province, Argentina [Paracoccidioidomicosis en 
la provincia de Formosa, Argentina]. Rev Argent Microbiol. 2008; 40:24-9.

44. - Batista J Jr, de Camargo ZP, Fernandes GF, et al. Is the geographical origin of a Paracoccidioides brasiliensis isolate important for antigen production for regional diagnosis of paracoccidioidomycosis? Mycoses 2010;53:176-180. This paper explores the possibility of molecular differences in Paracoccidioides brasiliensis, which could be related to the geographic origin of the species and may result in problems in diagnostic testing.

45. Matute D, Quesada-Ocampo LM, Rauscher JT, McEwen JG. Evidence for positive selection in putative virulence factors within the Paracoccidioides brasiliensis species complex. PLos Negl Trop Dis. 2008;2:e296.

46. - Pinzan CF, Ruas LP, Casabona-Fortunato AS, et al. Immunological basis for the gender differences in murine Paracoccidioides brasiliensis infection. PLos ONE 2010;5:e10757. This paper describes a murine model showing differences in gender in the immunologic response against Paracoccidioides brasiliensis.

47. de Freitas RM Costa, et al. Pulmonary paracoccidioidomycosis: radiology and clinical-epidemiological evaluation. Rev Soc Bras Med Trop. 2010;43:651-6.

48. Miranda-Paniago AM, Aguilar JI, Aguilar ES, et al. Paracoccidioidomycosis: a clinical and epidemiological study of 422 cases observed in Mato Grosso do Sul [Estudo clínico e epidemiológico de 422 casos observados no Estado de Mato Grosso do Sul.]. Rev Soc Bras Med Trop. 2003;36:455-9.

49. Brazao-Silva MT, Andrade MF, Franco T, et al. Paracoccidioidomycosis: a series of 66 patients with oral lesion from an endemic area. Mycoses. 2011;54:e189-195.

50. Queiroz-Telles F, Goldani LZ, Schlamm HT, et al. An open-label comparative pilot study of oral voriconazole and itraconazole for long-term treatment of paracoccidioidomycosis. Clin Infect Dis. 2007;45:1462-9.

51. Prado M, Silva MB, Laurenti R, et al. Mortality due to systematic mycosis as a primary cause of death or in association with AIDS in Brazil: a review from 1996 to 2006. Mem Inst Oswaldo Cruz. 2009;104:513-21.

52. Leroy O, Gangneux JP, Montravers P, et al. Epidemiology, management, and risk factors for death of invasive Candida infections in critical care: a multicenter, prospective, observational study in France (2005-2006). Crit Care Med. 2009;37:1612-8.

53. Corzo DE, Cornejo DP, Sifuentes-Osornio J. Surveillance of Candida spp bloodstream infections and analysis of the risk factors for death: Experience in two National Institutes of Health, 2008-2010 [Vigilancia epidemiológica de las infecciones hematógenas por Candida spp. y análisis de los factores de riesgo de muerte: estudio en dos Institutos Nacionales de Salud, 20082010]. XXXVI Congr Nal Infect Microbiol Clin, Puebla, Mexico. June 15-18, 2011.

54. Colombo AL, Guimaraes T, Silva LR, et al. Prospective observational study of candidemia in Sao Paulo, Brazil: incidence rate, epidemiology and predictors of mortality. Infect Control Hosp Epidemiol. 2007;28:570-6.

55. Colombo AL, et al. Epidemiology of candidemia in Brazil: a nationwide sentinel surveillance of candidemia in eleven medical centers. J Clin Microbiol. 2006;44:2816-23.

56. Pfaller MA, Diekema DJ, Gibbs DL, et al. Results from the ARTEMIS DISK Global Antifungal Surveillance Study, 1997 to 2007: a 10.5-year analysis of susceptibilities of Candida species to fluconazole and voriconazole as determined by CLSI standardized disk-diffusion. J Clin Microbiol. 2010;48: 1366-77.

57. Bruder-Nascimento A, Camargo CH, Sugizaki MF, et al. Species distribution and susceptibility profile of Candida species in a Brazilian public tertiary hospital. BMC Res notes. 2010;3:1-5.
58. González GM, Elizondo M, Ayala J. Trends in species distribution and susceptibility of bloodstream isolates of Candida collected in Monterrey, Mexico, to seven antifungal agents: results of a 3 year (2004-2007) surveillance study. J Clin Microbiol. 2008;46:2902-5.

59. Diaz-Granados CA, Martínez A, Deaza C, Valderrama S. An outbreak of Candida spp. bloodstream infection in a tertiary care center in Bogotá, Colombia. Braz J Infect Dis. 2008;12: $390-4$.

60. Rodero L, Davel G, Soria M, et al. Multicenter study of fungemia due to yeast in Argentina [Estudio multicéntrico de fungemias por levaduras en la República de Argentina]. Rev Argent Microbiol. 2005;37:189-95.

61. Giusiano G, Mangiaterra M, Saito VG, et al. Etiology of fungaemia and catheter colonization in Argentinean paediatrics patients. Mycoses. 2006;49:49-54.

62. Hernández-Dueñas AMR, Vázquez-Larios MR, Soto-Nieto GI, Rivera-Martínez E. Drug susceptibility of yeasts isolated from books from patients of the Instituto Nacional de Cardiologia Ignacio Chavez. [Susceptibilidad de levaduras aisladas de hemocultivos en pacientes del Instituto Nacional de Cardiología Ignacio Chávez]. Rev Inv Clin. 2009;61:294-9.

63. Arcaya NM, Mesa LM, Pineda MR, et al. Antifungal drug susceptibility profile among Candida species in blood isolates from patients at the University Hospital, Maracaibo, Venezuela. [Perfil de sensibilidad antifúngica de especies de Candida aisladas de hemocultivos en un hospital Universitario, Maracaibo, Venezuela]. Rev Iberoam Micol. 2006;23:97-100.

64. Panizo MM, Reviákina V, Dolande M, et al. Candida spp. in vitro susceptibility profile to four antifungal agents. Resistance surveillance study in Venezuelan strains. Med Mycol. 2009;47:137-43.

65. Santos PE, Córdoba S, Carrillo-Muñoz A, et al. Epidemiology of fungaemia in a paediatric hospital of high complexity [Epidemiología de las fungemias en un hospital pediátrico de alta complejidad]. Rev Iberoam Micol. 2010;27:200-2.

66. Reséndiz SJ, Morales AJJ. Risk factors of mortality in fungemias caused by Candida sp. in children. [Factores asociados a mortalidad por fungemias causadas por Candida sp. en niños]. Bol Med Hosp Infant Mex. 2007;64:91-8.

67. Ajenjo MC, Aquevedo A, Guzmán AM, et al. Epidemiologic profile of invasive candidiasis in patients at the intensive care unit at a university hospital [Perfil epidemiológico de la candidiasis invasora en unidades de pacientes críticos en un hospital universitario]. Rev Chilena Infectol. 2011;28:118-22.

68. Rodríguez AZ, Gómez C de B, Restrepo CA, et al. Antimicrobial susceptibility to fluconazole and voriconazole among Candida spp. isolated in ICU patients from Medellin, Colombia. [Sensibilidad a fluconazol y voriconazol de especies de Candida aisladas de pacientes provenientes de unidades de cuidados intensivos en Medellin, Colombia (2001-2007)]. Rev Iberoam Micol 2010;27:125-129.

69. • Nucci M, Alvarado T, Tiraboschi N, et al. Epidemiology of candidemia in Latin America: Preliminary results of a prospective laboratory-based survey. 50th ICAAC, Boston, Mass, September 2-15, 2010. This preliminary report of the first multicenter Latin American study on candidemia, which includes information from 9 countries, reports the epidemiology and drug susceptibility from all species of Candida obtained from blood cultures.

70. Lin X. Cryptococcus neoformans: Morphogenesis, infection and evolution. Infect Genet Evol. 2009;9:401-16.

71. Castañon-Olivares LR, Martínez KM, Cruz RM, et al. Genotyping of Mexican Cryptococcus neoformans and C. gatti isolates by PCR-fingerprinting. Med Mycol. 2009;47:713-21.

72. Quinet-Leiman BC, Jorge-Koifman R. Official information systems for cryptococcal meningitis, state of Rio de Janeiro, Southeastern Brazil. Rev Saúde Pública. 2009;43:1-4. 
73. da Cunha Colombo ER, Mora DJ, Silva-Vergara ML. Immune reconstitution inflammatory syndrome (IRIS) associated with Cryptococcus neoformans infection in AIDS patients. Mycoses. 2011;54:e178-82.

74. Lizarazo J, Linares M, de Bedout C, et al. Clinical and epidemiologic study of cryptococcosis in Colombia: a nine-year national survey 1997-2005 [Estudio clínico y epidemiológico de la criptococcosis en Colombia: resultados de nueve años de la encuesta nacional, 1997-2005]. Biomédica. 2007;27:94-109.

75. Meyer W, Castañeda A, Jackson S, et al. Molecular typing of Iberoamerican Cryptococcus neoformans Isolates. Emerg Infect Dis. 2003;9:189-95.

76. Leal AL, Faganello J, Fuentefria AM, et al. Epidemiological profile of cryptococcal meningitis patients in Rio Grande do Sul, Brazil. Mycopathologia. 2008;166:71-5.

77. Lindenberg A, Chang M, Paniago A, et al. Clinical and epidemiological features of 123 cases of cryptococcosis in Mato Grosso do Sul, Brazil. Rev Inst Med Trop Sao Paulo. 2008;50:75-8.

78. Pappalardo M, Paschoal R, Melhem M. AIDS-associated central nervous system cryptococcosis: a Brazilian case study. AIDS. 2007;21:1971-3.

79. Ribeiro LC, Hahn RC, Favalessa OC. Systemic mycosis: factors associated with death among patients infected with human immunodeficiency virus Cuiaba, state of Mato Grosso, Brazil, 2005-2008 [Micoses sistemicas: fatores associados ao obito em pacientes com infecção pelo vírus da imunodeficiência humana, Cuiabá, Estado de Mato Grosso, 2005-2008.]. Rev Soc Bras Med Trop. 2009;42:698-705.

80. Pfaller MA, Messer SA, Boyken L, et al. Global trends in the antifungal susceptibility of Cryptococcus neoformans (1990 to 2004). J Clin Microbiol. 2005;43:2163-7.

81. Rabagliati R, Fuentes LG, Guzman DAM, et al. Fungal invasive disease in onco-hematologic patients and recipients of bone-marrow transplantation [Enfermedad fúngica invasora en pacientes hematooncológicos y receptores de trasplante de precursores hematopoyéticos bajo la perspectiva de los conceptos diagnósticos de EORTC/ MSG]. Rev Chilena Infect. 2009;26:212-9.

82. Davel G, Canteros CE. Current situation of the mycosis in Argentina [Situación de las micosis en la República de Argentina]. Rev Argent Microbiol. 2007;39:28-33.

83. - Villarroel M, Aviles CL, Silva P, et al. Risk factors associated with invasive fungal disease in children with cancer and febrile neutropenia. Pediatr Infect Dis J 2010;29:816-821. This paper describes IFIs from a multicenter clinical study in a Latin American country.

84. Rodrigues-Aquino V, Vercosa EB, Falhauber G, et al. Distribution of filamentous fungi causing invasive fungal disease at the Haematological Unit, Hospital de clínicas de Porto Alegre, Brazil. Braz J Infect Dis. 2010;14:277-80.

85. Cruz R, Piontelli LE. Invasive fungal disease in patients from five hospitals in the Valparaiso region, Chile: 2004 to 2009. [Enfermedad fúngica invasora en pacientes de 5 hospitales de la Región de Valparaíso, Chile. 2004-2009]. Rev Chilena Infectol. 2011;28:123-9.

86. Carvalho-Dias VM, Sola CB, Cunha CA, et al. Invasive aspergillosis in hematopoietic stem cell transplant recipients. Braz J Infect Dis. 2008;12:385-9.

87. Nucci M, Noùer SA, Grazziutti, et al. Probable invasive aspergillosis without prespecified radiologic findings: proposal for inclusion of a new category of Aspergillosis, and implications for studying novel therapies. Clin Infect Dis. 2010;51:1273-80.

88. Nouér S, Nucci M, Kumar NS, et al. Earlier response assessment in invasive Aspergillosis based on the kinetics of serum Aspergillus galactomannan: proposal for a new definition. Clin Infect Dis. 2011;53:671-6.
89. Frías-De León MG, Zavala-Ramirez M, Cordoba S, et al. Phenotypic characteristic of Aspergillus section fumigate from different geographic origins and their relationships with genotypic characteristics. BMC Infect Dis. 2011;11:116.

90. Messer SA, Jones RN, Fritsche TR. International surveillance of Candida spp. and Aspergillus spp.: report from the SENTRY Antimicrobial Surveillance Program (2003). J Clin Microbiol. 2006;44:1782-7.

91. Nunes Mdo C, Barbosa FB, Gomes GH, et al. Fatal right-sided endocarditis caused by Fusarium in an immunocompromised patient: a case report. Mycoses. 2011;54:460-2.

92. Nucci M, Marr KA, Queiroz-Telles F, et al. Fusarium infection in hematopoietic stem cell transplant recipients. Clin Infect Dis. 2004;38:1237-42.

93. Nucci M, Anaissie E. Cutaneous infection by Fusarium species in healthy and immunocompromised host: implications for diagnosis and management. Clin Infect Dis. 2002;35:909-20.

94. Córdoba S, Rodero L, Vivot W, et al. In vitro interactions of antifungal agents against clinical isolates of Fusarium spp. Int $\mathrm{J}$ Antimicrob Agents. 2008;31:171-4.

95. Yun-Sun H, Singh N. Mucormycosis: its contemporary face and management strategies. Lancet Infect Dis. 2011;11:301-11.

96. Arce-Salinas CA, Pérez-Silva E. Mucormycosis complication in systemic lupus erythematosus. Lupus. 2010;19:985-8.

97. Ayala-Gaytán JJ, Petersen-Morfín S, Guajardo-Lara CE, et al. Cutaneous zygomycosis in immunocompetent patients in México. Mycoses. 2010;53:538-40.

98. Severo LC, Oliveira FD, Dreher R, et al. Zygomycosis: a report of eleven cases and a review of the Brazilian literature. Rev Iberoam Micol. 2002;19:52-6.

99. Ramírez C, Hernández AF, Méndez V, et al. Case report of mucormycosis in a patient with secondary methimazole-induced agranulocytosis [Mucormicosis en un paciente con agranulocitosis secundaria a metimazol. Informe de un caso.]. Gac Med Mex. 2009;145:235-8.

100. Auxiliadora-Martínez M, Alkmim-Teixeira GC, Machado-Viana $\mathrm{J}$, et al. Meningoencephalitis caused by a zygomycete fungus (Basidiobolus) associated with septic shock in an immunocompetent patient: 1-year follow-up after treatment. Braz J Med Biol Res. 2010;43:794-8.

101. Tapia EO, Chahín AC, Concha FC. Primary cutaneous mucormycosis: report of two cases and review. [Mucormicosis cutánea primaria: a propósito de 2 casos. Revisión de la literatura]. Rev Chilena Infectol. 2011;28:269-73.

102. Passos XS, Sales WS, Maciel PJ, et al. Nosocomial invasive infection caused by Cunninghamella bertholletiae: case report. Mycopathologia. 2006;161:33-5.

103. Saravia-Flores M, Guaran DM, Argueta V. Invasive cutaneous infection, caused by Apophysomyces elegans associated with a spider bite. Mycoses. 2009;53:259-61.

104. Cortés JA, Reyes P, Gómez C, et al. Fungal bloodstream infection in tertiary care hospital in Colombia. Rev Iberoam Micol. 2011;28:74-8.

105. Pérez C, Dolande M, Moya M, et al. Cryptococcus neoformans, Cryptococcus gatti. Serotypes in Venezuela. Mycopathologia. 2008;166:149-53.

106. Souza LK, Souza Junior AH, Costa CR, et al. Molecular typing and antifungal susceptibility of clinical and environmental Cryptococcus neoformans species complex isolates in Goiania, Brazil. Mycoses. 2008;53:62-7.

107. Trilles L, Lazera Mdos S, Wanke B, et al. Regional pattern of the molecular types of Cryptococcus neoformans and Cryptococcus gattii in Brazil. Mem Inst Oswaldo Cruz. 2008;103:455-62. 